\title{
PENINGKATAN KETERAMPILAN MENULIS PARA GRAF MELALUI PENERAPAN KEGIATAN MENULIS JURNAL DAN PEMANFAATANYA UNTUK PENILAIAN AUTENTIK PADA SISWA KELAS VIII SMP NEGERI 5 SIMPANG EMPAT KABUPATEN BANJAR
}

\author{
Siti Faridah \\ Dosen FKIP Universitas Achmad Yani Banjarmasin \\ email: faridahsiti69@yahoo.com
}

\begin{abstract}
Abstrak
Pendekatan yang digunakan dalam penelitian ini adalah pendekatan kualitatif, sedangkan rancangan penelitian yang digunakan adalah penelitian tindakan kelas. Rancangan penelitian tindakan kelas tersebut dilakukan dalam tiga siklus penelitian. Subjek penelitiannya adalah siswa kelas VIII SMP Negeri 5 Simpang Empat kabupaten Banjar. Hasil penelitian menunjukkan bahwa kegiatan tersebut dapat meningkatkan keterampilan menulis paragraf siswa, baik dari segi kuantitas maupun kualitas paragraf yang dihasilkan. Kegiatan menulis jurnal juga membuat kegiaan menulis menjadi lebih menarik dan bermakna bagi siswa. Peningkatan tersebut tidak terlepas dari upaya guru memberi respon, mengembangkan dialog, memodelkan cara menulis paragraf yang benar, mencermati kesalahan yang kerap dilakukan siswa, membiasakan secara tetap, serta memberikan berbagai arahan untuk membangkitan kreativitas siswa dalam menulis paragraf. Bimbingan dan arahan guru itu tetap diberikan, meskipun menulis jurnal adalah kegiatan menulis yang bersifat informal.
\end{abstract}

Kata Kunci: menulis paragraf, menulis jurnal, penilaian autentik

\section{PENDAHULUAN}

Pembelajaran bahasa Indonesia secara fungsional dan komunikatif adalah pembelajaran yang lebih menekankan siswa untuk belajar berbahasa, dalam kaitannya dengan fungsi bahasa sebagai alat untuk berkomunikasi. Siswa bukan sekedar belajar tentang pengetahuan bahasa, melainkan belajar menggunakan bahasa untuk keperluan berkomunikasi. Untuk itu, pendekatan pembelajaran yang sesuai adalah pendekatan komunikatif.

Salah satu aspek keterampilan berbahasa yang berkaitan dengan pengungkapan pikiran, gagasan, pendapat, dan perasaan tersebut adalah keterampilan menulis paragraf. Keterampilan menulis paragraf sebagai keterampilan berbahasa yang bersifat produktifaktif merupakan salah satu kompetensi dasar berbahasa yang harus dimiliki siswa agar terampil berkomunikasi secara tertulis. Siswa akan terampil mengorganisasikan gagasan dengan runtut, menggunakan kosakata yang tepat dan sesuai, memperhatikan ejaan dan tanda baca yang benar, serta menggunakan ragam kalimat yang variatif dalam menulis jika memiliki kompetensi menulis paragraf yang baik.

Berdasarkan pengalaman dan pengamatan di kelas, ditemukan bahwa menulis kerap kali menjadi suatu hal yang kurang diminati dan kurang mendapat respon yang baik dari siswa. Siswa tampak mengalami kesulitan ketika harus menulis. Siswa tidak tahu apa yang harus dilakukan ketika pembelajaran menulis dimulai. Mereka terkadang sulit sekali menemukan kalimat pertama untuk memulai paragraf. Siswa kerap menghadapi sindrom kertas kosong (blank page syndrome) tidak tahu apa yang akan ditulisnya. Mereka takut 
salah, takut berbeda dengan apa yang diinstruksikan gurunya.

Keterampilan menulis di kelas terkadang juga hanya diajarkan pada saat pembelajaran menulis saja, padahal pembelajaran keterampilan menulis dapat dipadukan atau diintegrasikan dalam setiap proses pembelajaran di kelas. Pengintegrasian itu dapat bersifat internal dan eksternal. Pengintegrasian internal berarti pembelajaran menulis diintegrasikan dalam pembelajaran keterampilan bebahasa yang lain. Menulis dapat pula diintegrasikan secara eksternal dengan mata pelajaran lain di luar mata pelajaran bahasa Indonesia.

Kecenderungan lain yang terjadi adalah pola pembelajaran menulis di kelas yang dikembangkan dengan sangat terstruktur dan mekanis, mulai dari menentukan topik, membuat kerangka, menentukan ide pokok paragraf, kalimat utama, kalimat penjelas, ketepatan penggunaan pungtuasi (tandabaca) dan sebagainya. Pola tersebut selalu berulang tiap kali pembelajaran menulis. Pola tersebut tidak salah, tetapi pola itu menjadi kurang bermakna jika diterapkan tanpa variasi strategi dan teknik lain. Akibatnya, waktu pembelajaranpun lebih tersita untuk kegiatan tersebut, sementara kegiatan menulis yang sebenarnya tidak terlaksana atau sekedar menjadi tugas di rumah. Kegiatan menulis seperti ini bagi siswa menjadi suatu kegiatan yang prosedural dan menjadi tidak menarik. Penekanan padahal yang bersifat mekanis adakalanya membuat kreatifitas menulis tidak berkembang karena hal itu tidak mengizinkan gagasan tercurah secara alami. Bahkan,Tompkins (1994:105) menegaskan bahwa terlalu menuntut kesempurnaan hasil tulisan dari siswa justru dapat menghentikan kemauan siswa untuk menulis.

Pembelajaran menulis juga sering membingungkan siswa karena pemilahanpemilihan yang kaku dalam mengajarkan jenis-jenis tulisan atau jenis-jenis paragraf, seperti narasi, eksposisi, deskripsi, dan argumentasi. Pengkategorian yang kaku itu membuat siswa menulis terlalu berhati-hati karena takut salah, tidak sesuai dengan jenis karangan yang dituntut. Padahal, ketakutan untuk berbuat salah tersebut dapat mematikan kreativitas siswa untuk menulis. Selain itu, Halliday (dalam Tompkins \& Hoskisson, 1991: 187) menyatakan bahwa pengkategorian jenis-jenis karangan tersebut terlihat artifasial ketika kita meminta siswa menggunakannya untuk berbagai tujuan yang berbeda, sebab siswa terkadang mengkombinasikan dua atau lebih kategori untuk mengemukakan sebuah gagasan dalam tulisannya.

Menulis merupakan suatu keterampilan dan keterampilan itu hanya akan berkembang jika dilatihkan secara terus menerus atau lebih sering. Memberikan kesempatan lebih banyak bagi siswa untuk berlatih menulis dalam berbagai tujuan merupakan sebuah cara yang dapat diterapkan agar keterampilan menulis meningkat dan berkembang secara cepat.

Permasalahan lain yang terkait dengan pembelajaran keterampilan menulis di sekolah adalah sistem penilaian dan pencapaian target kurikulum pembelajaran yang hanya diukur berdasarkan hasil tes-tes tertulis di akhir semester, atau tahun pelajaran. Padahal, tidak semua keterampilan berbahasa dapat dievaluasi dengan menggunakan paper and penciltests (Saukah, 1999). Untuk mengetahui kemampuan dan perkembangan keterampilan berbahasa, termasuk menulis tidak cukup hanya dilihat melalui jawaban soalsoal yang diberikan satu atau dua kali di tengah dan di akhir semester (subsumatif dan sumatif). Tes-tes tertulis hanya salah satu bagian saja dari proses penilaian.

Menyikapi hal tersebut perlu diterapkan suatu model penilaian keterampilan menulis yang autentik dan komprehensif dengan berbagai teknik dan prosedur. Model penilaian tersebut melihat perkembangan dan keberhasilan keterampilan berbahasa siswa secara berkelanjutan (Pulh, 1997: 6). Penilaian tersebut juga harus dilakukan secara autentik, yaitu didasarkan proses perkembangan dan data-data autentik yang menggambarkan keterampilan berbahasa yang dikuasainya (Nurhadi, 2003: 19). Dalam konteks yang lebih komunikatif, penilaianpun tidak hanya dilakukan oleh guru, siswa dapat belajar saling 
menilai dengan temannya, bahkan belajar menilai dirinya sendiri.

\section{Rumusan Masalah}

Berdasarkan latar belakang dan fokus masalah, maka masalah dalam penelitian ini secara umum adalah "bagaimanakah upaya meningkatkan keterampilan menulis paragraf siswa kelas VIII SMP Negeri 5 Simpang Empat Kabupaten Banjar melalui penerapan kegiatan menulis jurnal dan pemanfaatannya untuk penilaian autentik?". Rumusan masalah umum itu dirinci menjadi tiga masalah khusus. Ketiga masalah khusus tersebut adalah sebagai berikut:

1. Bagaimanakah upaya meningkatkan keterampilan menulis paragraf siswa kelas VIII SMP Negeri 5 Simpang Empat melalui tindakan pemahaman konsep dan pemodelan kegiatan menulis jurnal?

2. Bagaimanakah upaya meningkatkan keterampilan menulis paragraf siswa kelas VIII SMP Negeri 5 Simpang Empat melalui tindakan pelaksanaan dan pembiasaan kegiatan menulis jurnal dalam pembelajaran?

3. Bagaimanakah upaya meningkatkan keterampilan menulis paragraf siswa kelas VIII SMP Negeri 5 Simpang Empat melalui tindakan penilaian autentik dengan memanfaatkan tulisan-tulisan dalam jurnal siswa?

\section{Tujuan Penelitian}

Secara umum tujuan penelitian ini adalah mendapatkan kajian tentang upaya meningkatkan keterampilan menulis paragraf siswa kelas VIII SMP Negeri 5 Simpang Empat Kabupaten Banjar melalui kegiatan menulis jurnal dan pemanfaatannya untuk penilaian autentik.Tujuan penelitian umum itu diuraikan secara khusus sebagai berikut:

1. Mendapatkan kajian tentang upaya meningkatkan keterampilan menulis paragraf siswa kelas VIII SMP Negeri 5 Simpang Empat melalui tindakan pemahaman konsep dan pemodelan.

2. Mendapatkan kajian tentang upaya meningkatkan keterampilan menulis paragraf siswa kelas VIII SMP Negeri 5 Simpang Empat melalui tindakan pelaksanaan dan pembiasaan menulis jurnal dalam pembelajaran.

3. Mendapatkan kajian tentang upaya meningkatkan keterampilan menulis paragraf siswa kelas VIII SMP Negeri 5 Simpang Empat melalui tindakan penilaian autentik dengan memanfaatkan tulisan-tulisan dalam jurnal siswa.

\section{Manfaat Penelitian}

Kegiatan dan laporan hasil penelitian ini dapat memberikan manfaat baik yang bersifat teoritis maupun praktis. Manfaat teoritisnya yaitu memberi sumbangan informasi dan masukan bagi pengembangan teori pembelajaran keterampilan menulis dan pengembangan teori penilaian autentik dalam pembelajaran bahasa Indonesia. Hasil penelitian ini juga memiliki manfaat praktis bagi guru, siswa, dan sekolah dalam upaya peningkatan kualitas pembelajaran keterampilan menulis.

Bagi guru, hasil penelitian ini dapat dimanfaatkan sebagai masukan dan pertimbangan empiris dalam memilih strategi alternatif dan menerapkan penilaian autentik dalam pembelajaran menulis sebagai upaya meningkatkan keterampilan menulis siswa. Selainitu; hasil penelitian ini diharapkan dapat mendorong guru untuk meneliti lebih lanjut tentang berbagai strategi pembelajaran dan proses penilaian keterampilan menulis, dalam kaitannya dengan pengembangan profesi.

Bagi siswa, kegiatan atau tindakan dilakukan dalam penelitian ini juga bermanfaat yaitu memberikan variasi kegiatan pembelajaran yang lebih menarik dan bermakna. Siswa dapat berlatih mengekspresikan diri, mengemukakan gagasan, atau perasaannya secara 
tertulis dengan lebih bebas dan lebih sering. Dengan berlatih menulis jurnal secara lebih sering dan lebih bebas, diharapkan keterampilan menulis siswa khususnya keterampilan menulis paragraf dapat menjadi lebih baik.

Bagi sekolah atau lembaga pendidikan, hasil penelitian ini bermanfaat sebagai bahan pertimbangan pemikiran dalam rangka perbaikan kualitas pembelajaran dan kualitas sekolah.Hasil penelitian ini juga dapat dijadikan referensi dan bahan pertimbangan bagi pengembangan kurikulum, perangkat pembelajaran; dan proses penilaian pembelajaran yang lebih baik.

\section{KAJIAN TEORI}

\section{Kegiatan Menulis Jurnal sebagai Alternatif Tindakan}

Salah satu cara alternatif yang dapat diterapkan untuk membiasakan dan melatihkan keterampilan menulis pada siswa, khususnya menulis paragraf adalah dengan menulis jurnal atau dalam istilah yang lebih umum dikenal dengan menulis buku harian. Pembiasaan dan rutinitas menulis tersebut akan menjadi suatu kebiasaan perilaku yang positif. Dengan menulis jurnal. Siswa dapat berlatih menulis lebih sering dan lebih bebas di luar jam pembelajaran menulis secara khusus. Siswa akan terbiasa mengungkapkan gagasan atau perasaannya secara tertulis dalam bentuk paragraf-paragraf yang baik. Jurnal dapat menjadi sarana yang membantu siswa untuk belajar menulis dengan lebih menyenangkan dan berhasil (Eanes, 1997: 457).

Kegiatan menulis jurnal itu tidak hanya dilakukan ketika pembelajaran menulis, pada pembelajaran bahasa Indonesia dengan fokus keterampilan lain kegiatan tersebut juga dapat disisipkan. Guru dapat menyediakan waktu setiap hari atau beberapa hari dalam seminggu sekitar sepuluh sampai dengan lima belas menit bagi siswa untuk menulis jurnal pribadinya (Capacchione, 1989: 15; Tompkins \& Hoskisson, 1991: 189). Dalam konteks sistem pembelajaran sekolah di Indonesia sekilas terkesan penyediaan waktu ini mengurangi alokasi waktu pembelajaran pokok, tetapi bila disadari lebih jauh pengurangan alokasi waktu pembelajaran ini, yang dimanfaatkan untuk menulis jurnal, dapat memberi manfaat yang besar bagi siswa.

Rutinitas menulis jurnal yang dilakukan siswa memberi manfaat positif bagi perkembangan kemampuan menulis. Selainitu, dapat pula meningkatkan penguasaan aspek pembahasaan yang lain secara tidak langsung. Secara berkesinambungan siswa akan terlatih mengemukakan gagasan dan perasaannya dengan pilihan kata, kalimat; struktur penyajian, dan pola pengembangan yang baik. Sebab, untuk terampil menulis, anak-anak harus sering dan bebas menulis (serta membaca) supaya mereka terampil dalam menggunakan struktur yang kompleks dan benar secara tata bahasa (Leonhardt,2001:22).

Kegiatan menulis jurnal mengajak siswa untuk lebih bebas dan kreatif mengekspresikan diri lewat bahasa tulis. Dalam kegiatan menulis jurnal, kemampuan komunikasi secara tertulis dikembangkan, siswa mengkomunikasikan hal-hal yang mereka amati, berbagai informasi, dan berbagai ide (Saukah, 2000). Dalam jurnal siswa dapat menuliskan berbagai hal, tanpa tekanan dan ketakutan membuat kesalahan. Jika anak terbiasa menulis secara mandiri, maka mereka akan belajar cara menulis dengan fokus yang tajam dan jelas(Leonhard, 2001:21).

Tulisan dalam jurnal merupakan produk yang alamiah dan bersifat spontan. Siswa dapat menuliskan pengalaman keseharian yang dialami atau dirasakannya,tanggapannya tentang kegiatan pembelajaran, tanggapannya tentang suatu bacaan yang dibacanya, tanggapan terhadap lingkungan disekitarnva atau hal-hal lain yang menurutnya menarik untuk ditulis. Melalui kegiatan menulis jurnal siswa berlatih dan membiasakan diri mengemukakan gagasan, mengekspresikan diri, atau menanggapi hal-hal yang menarik perhatiannya dalam bentuk paragraf-paragraf. Kegiatan menulis jurnal ini memberikan 
kesempatan siswa untuk menulis dengan lebih bebas untuk keperluan tugas-tugas menulis secara formal,tulisan dalam jurnal dapat menjadi pilihan sumber ide awal untuk dikembangkan.

Konsep jurnal dalam penelitian ini adalah tulisan-tulisan yang ditulis siswa dalam buku catatan khusus yang sifat informal, spontan, rutin, dan personal. Hal-hal yang ditulis adalah tentang pengalaman pribadi, curahan perasaan atau gagasan, tanggapan tentang bacaan, tanggapan tentang proses pembelajaran atau hal-hal lain yang menarik minat dan perhatian siswa. Topik-topik yang ditulis dalam jurnal itu dapat dipilih secara bebas atau ditentukan sesuai konteks pembelajaran. Selanjutnya, tulisan siswa tersebut diberi respon oleh guru sebagai upaya meningkatkan motivasi siswa untuk menulis.

Sebagai tulisan informal maka aspek yang ditekankan dalam menulis jurnal adalah kelancaran/kefasihan (fluency) dalam mengemukakan suatu gagasan secara tertulis. Kejelasan isi tulisan lebih ditekankan daripada aspek-aspek mekanik, seperti ketepatan ejaan atau penggunaan pungtuasi. Namun, bukan berarti aspek mekanik diabaikan oleh guru dalam pembelajaran. Justru sebaiknya, tulisan-tulisan jurnal siswa dapat menjadi bahan acuan dan refleksi bagi guru untuk mengetahui tingkat pemahaman dan penguasaan siswa terhadap aspek-aspek tersebut.

Meskipun tulisan dalam jurnal siswa bersifat bebas, tulisan-tulisan tersebut tetap dapat dipantau dan mendapat respon dari guru. Respon yang diberikan bukan sekedar mengoreksi kesalahan-kesalahan mekanis penulisan, tetapi berupa respon yang lebih bersifat positif. Respon positif itu berupa komentar atau tanggapan yang berhubungan dengan isi tulisan sehingga dapat menjadi penguatan atau motivasi bagi siswa untuk terus menulis. Tulisan-tulisan respon itu juga tidak lebih panjang dari tulisan siswa dan ditulis dengan kalimat yang baik dan benar, sehingga tulisan tersebut dapat menjadi model bagi siswa. Kegiatan pemberian respon secara tertulis itu memungkinkan terjalinnya interaksi dinamis antara guru dan siswa lewat bahasa tulis, dalam konteks pendekatan komunikatif pembelajaran bahasa.

Dalam pelaksanaannva kegiatan menulis jurnal dapat dilakukan melalui tiga tahapan. Ketiga tahapan itu adalah (1) tahap pendahuluan. (2) tahap pelaksanaan, dan (3) Tahap penilaian. Pada tahap pendahuluan, kegiatan pokoknya terdiri dari pemahaman konsep dan pemodelan kegiatan yang akan dilakukan. Pada tahap pelaksanaan. Kegiatan pokoknya adalah pengintegrasian menulis jurnal dalam pembelajaran, pembiasaan menulis jurnal secara berlanjut, pemberian penguatan dan respon guru, serta pemberian bimbingan. Untuk mengembangkan kreativitas siswa dalam menulis. Pada tahap penilaian, kegiatan penilaian yang dilakukan dalam bentuk penilaian proses dan penilaian hasil.

\section{METODEPENELITIAN}

\section{Pendekatan dan Rancangan Penelitian}

Pendekatan yang digunakan dalam penelitian ini adalah pendekatan kualitatif Penggunaan pendekatan kualitatif ini didasari pemikiran bahwa penelitian ini berupaya untuk mengungkapkan berbagai gejala yang memberikan makna dan informasi sesuai konteks dan tujuan penelitian melalui pengumpulan data. Pengumpulan data tersebut dilakukan pada latara lamiah dengan peneliti sebagai instrumen utama dalam pengumpulan data.

Sejalan dengan pemfokusan dan latar alaminya yang berwujud aktivitas di dalam kelas, rancangan penelitian tindakan yang diterapkan adalah penelitian tindakan kelas (classroomactionreserch).

Berdasarkan pendekatan dan rancangan PTK yang akan diterapkan, prosedur dan langkah-langkah penelitian ini mengikuti prinsip-prinsip dasar penelitian tindakan. Oleh karena itu, model rancangan penelitian tindakan kelas yang akan digunakan adalah model 
spiral-bersiklus sebagaimana dikemukakan Lewin dan dikembangkan oleh Kemmis dan Elliot (Elliot,1991:71). Secara umum model siklus ini meliputi (1) perencanaan, (2) pelaksanaan tindakan, (3) pengamatan, (4) analisis dan refleksi.

\section{Subjek Penelitian}

Subjek penelitian ini adalah siswa kelas VIII SMP Negeri 5 Simpang Empat. Seluruh siswa akan dikenai tindakan karena penelitian tindakan kelas adalah penelitian yang mengikuti alur pembelajaran sebenarnya. Pertimbangan pemilihan kelas VIII sebagai sumber data penelitian karena kelas VIII merupakan kelas peneliti dalam melaksanakan tugas sehari-hari dan di kelas ini terdapat masalah tersebut. Selain itu, kelas VIII SMP merupakan kelas tengah, dengan siswa yang telah dapat berpikir secara logis dan abstrak serta telah mempunyai dasar pengetahuan awal tentang keterampilan menulis yang dipelajari di kelas VII. Pengetahuan awal tersebut, misalnya bentuk paragraf, pola-pola kalimat, penggunaan ejaan dan tanda baca.

\section{Data dan Teknik Pengumpulan Data}

Data yang ingin diperoleh adalah data tentang proses kegiatan dan data tentang hasil kegiatan menulis jurnal. Data-data itu meliputi (1) data awal tentang kemampuan keterampilan menulis paragraf siswa (2) data pokok tentang upaya peningkatan keterampilan menulis paragraf melalui tindakan pemahaman konsep dan pemodelan kegiatan menulis jurnal. (3) data pokok tentang upaya peningkatan keterampilan menulis paragraf melalui tindakan pelaksanaan dan pembiasaan kegiatan menulis jurna1, (4) data pokok tentang upaya peningkatan keterampilan menulis paragraf melalui tindakan penilaian autentik dengan memanfaatkan tulisan-tulisan dalam jurnal siswa, serta (S) data pendukung tentang perkembangan keterampilan menulis siswa setelah tindakan. Untuk memperoleh data penelitian, teknik pengumpulan data yang akan digunakan adalah wawancara, pengamatan, pendokumentasian, dan pemberian tes menulis. Sesuai dengan (karakteristik penelitian kualitatif, dalam penelitian ini peneliti berperan sebagai instrumen utama pengumpulan data. Data-data tersebut berupa transkrip wawancara dan rekaman kegiatan belajar, catatan lapangan dokumentasi hasil tulisan siswa dan hasil tes menulis.

\section{Analisis Data}

Analisis data dalam penelitian ini akan dilakukan dengan dasar analisis data model alir yang terdiri atas tiga tahapan yaitu (1) mereduksi data, (2) menyajikan data, dan (3) menarik kesimpulan dan memverifikasi. Analisis data tersebut dilakukan selama dan sesudah penelitian, mulai dari tahap perencanaan kegiatan, pelaksanaan, hingga refleksi kegiatan.

\section{HASIL PENELITIAN DAN PEMBAHASAN Perencanaan Tindakan}

Sesuai perencanaan yang telah dibuat tindakan pembelajaran dikembangkan dalam tiga siklus tindakan. Perencanaan yang dibuat, disesuaikan dengan satuan program semester yang telah disusun oleh guru mata pelajaran, sehingga pelaksanaan penelitian ini tetap berjalan sesuai alur progam pembelajaran mata pelajaran bahasa Indonesia sebagaimana mestinya. Kegiatan menulis jurnal dalam penelitian ini menjadi kegiatan suplemen yang terintegrasi dalam pembelajaran pokok.

Pelaksanaan setiap siklus terdiri atas tiga tindakan pokok. Adapun ketiga tindakan pokok tersebut adalah (1) pemahaman dan pemodelan. (2) Pelaksanaan dan pembiasaan kegiatan menulis jurnal, dan (3) pelaksanaan penilaian autentik melalui jurnal. Dalam tiap siklus, tindakan pertama dilaksanakan dengan alokasi waktu dua kali pertemuan jam 
pelajaran. Tindakan kedua dilakukan terintegrasi dalam tiap jam pelajaran bahasa Indonesia selama empat kali pertemuan, guru menyediakan waktu sepuluh sampai dengan lima belas menit di menit awal atau di akhir pelajaran untuk menulis. Materi tulisan jurnal disesuaikan dengan konteks materi pembelajaran saat itu. Tindakan ketiga selain dilakukan secara berkesinambungan, dilakukan pula oleh siswa sekitar dua puluh menit pada waktu yang ditentukan. Setiap siklus siswa menulis jurnal sebanyak lima kali.

\section{Pelaksanaan Tindakan}

Penelitian dilakukan dalam tiga siklus. Setiap siklus terdiri dari kegiatan perencanaan, pengamatan, analisis temuan, dan refleksi tindakan. Dalam tiap siklusnya dilakukan tiga pokok pembelajaran. Ketiga pokok pembelajaran itu adalah (1) kegiatan pemahaman konsep dan pemodelan kegiatan menulis jurnal, (2) pelaksanaan dan pembiasan menulis jurnal, dan (3) penilaian autentik dengan memanfaatkan tulisan dalam jurnal siswa.

\section{Pemahaman Konsep dan Pemodelan Kegiatan Menulis}

Dalam kegiatan pemahaman konsep dan pemodelan ini guru melakukan langkahlangkah pokok dalam pembelajaran. langkah-langkah tersebut, yaitu (1) menyampaikan tujuan dan pokok-pokok kegiatan pembelajaran. (2) membangkitkan skemata siswa. (3) menjelaskan dan mendiskusikan tentang menulis paragraf yang baik, (4) memberikan latihan dan contoh penulisan paragraf yang baik, (5) menghubungkan kegiatan menulis paragraf dengan menulis jurnal, (6) mendiskusikan dan menjelaskan tentang kegiatan menulis jurnal. (7) memajangkan contoh-contoh jurnal sebagai model serta (8) menulis jurnal tahap awal dengan mengamati model yang disajikan. Melalui kegiatan-kegiaian itu, siswa mampu mengkontruksi sendiri konsep pengetahuannya tentang menulis paragraf dengan pola pengembangan yang baik.

Untuk lebih mengefektifkan proses pembelajaran guru memanfaatkan media pembelajaran. Media digunakan berupa (1) lembar bagan struktur paragraf, (2) contohcontoh, tulisan yang dikutip dari jurnal siswa, dan (3) gambar-gambar tentang berbagai peristiwa aktual yang tengah terjadi.

\section{Pelaksanaan dan Pembiasaan Menulis Jurnal}

Pada siklus I kegiatan yang dilakukan pada tahap ini ada 6 langkah pokok. Keenam langkah pokok itu adalah (1) menyediakan waktu di awal pembelajaran untuk menulis, (2) meminta siswa menulis secara bebas tentang gagasan. Perasaan, atau berbagai hal yang dialaminya, (3) membantu memunculkan gagasan siswa melalui kegitan tanya jawab, (4) memantau dan membimbing siswa saat menulis. (5) memberi penguatan tiap kali perternuan, dan (6) mengumpulkan kembali buku jurnal yang telah ditulis untuk diberi respon pada siklus II langkah-langkah pembelajaran tersebut tetap sama, tetapi lebih bervariasi dibanding langkah-langkah pembelajaran pada siklus I. Pada pertemuan pertama, guru meminta Siswa untuk menulis tentang kegiatan kesehariannya, perasaan, pengalaman yang dialaminya, gagasan, atau tanggapannya tentang sesuatu. Pada pertemuan kedua, guru memancing gagasan siswa untuk menulis dengan berandai-andai melalui kegiatan tanyajawab.

Pada kegiatan ketiga, guru mengaitkan kegiatan menulis dengan peristiwa dengan peristiwa aktual yang terjadi. Pada kegiatan keempat kembali guru akan memberi kesempatan siswa mengekspresikan gagasannya secara bebas tentang pengalaman, perasaan. Atau tanggapannya terhadap suatu hal. Dalam tiap siklus, pelaksanaan dan pembiasaan menulis jurnal dilaksanakan sebanyak empat kali. Tiap dua kali pertemuan menulis jurnal diselingi dengan kegiatan penilaian siswa. Selama siswa menulis, guru senantiasa memberikan bimbingan yang dapat membangkitkan kreativitas siswa dalam 
menulis.

Pemberian respon diberikan guru secara tertulis, tetapi respon yang diberikan bukan hanya mengoreksi kesalahan siswa. Respon diberikan, mengarah pada tanggapan guru terhadap isi atau hal yang dikemukakan siswa.

\section{Pembahasan Hasil Peningkatan Kemampuan Menulis Paragraf Siswa}

Hasil penelitian tindakan ini menunjukkan bahwa dengan pembiasaan menulis jurnal secara berkelanjutan, siswa menjadi terbiasa menulis paragraf dan keterampilan menulis paragrafnya pun meningkat. Indikator peningkatan keterampilan menulis paragraf tersebut dapat dilihat dari tiga hal yaitu (1) kuantitas gagasan yang dihasilkan, (2) kualitas paragraf: dan ketuntasan aktivitas dan motivasi siswa.

Peningkatan pertama terlihat dari jumlah gagasan dan pilihan topik. Jumlah gagasan yang ditulis bertambah banyak serta memperlihatkan cara pemalu yang beragam, tidak ditemukan lagi paragraf yang hanya terdiri dari satu kalimat. Peningkatan tersebut terjadi pada tiap siklus tindakan. Hal tersebut secara lebih jelas dapat terlihat pada tabel 2 berikut:

Tabel 1. Perbandingan Rata-rata Jumlah Gagasan dalam Tulisan Siswa Tiap Siklus

\begin{tabular}{ccccc}
\hline \multirow{2}{*}{ SIKLUS } & \multicolumn{2}{c}{ PARAGRAF } & \multicolumn{2}{c}{ KALIMAT } \\
\cline { 2 - 5 } & Jumlah & Rata-Rata & Jumlah & Rata-rata \\
\hline Siklus I & 97 & 10,4 & 431 & 47,8 \\
\hline SiklusII & 120 & 13,3 & 554 & 61,6 \\
\hline SiklusIII & 132 & 14,7 & 606 & 67,3 \\
\hline
\end{tabular}

Kualitas paragraf yang dihasilkan memperlihatkan peningkatan. Peningkatan kualitas tersebut mencakup aspek pengembangan topik, pengorganisasian gagasan, penggunaan pilihan kata, tata bahasa, serta ejaan dan tanda baca yang secara bertahap semakin baik. Secara lebih jelas, hal tersebut tergambar dalam tabel berikut:

\section{Tabel2.Perbandingan Nilai Rata-Rata dan Kualifikasi Kualitas Tulisan Siswa Per} siklus.

\begin{tabular}{cccccc}
\hline \multicolumn{2}{c}{ Siktus I } & \multicolumn{2}{c}{ SiktusII } & \multicolumn{2}{c}{ SiktusIII } \\
\hline $\begin{array}{c}\text { NilaiRata- } \\
\text { Rata }\end{array}$ & Kualifikasi & $\begin{array}{c}\text { Nilai Rata- } \\
\text { Rata }\end{array}$ & Kualifikasi & Nilai Rata-Rata & Kualifikasi \\
\hline 2,3 & Cukup & 3,1 & Baik & 3,4 & Baik \\
\hline
\end{tabular}

Dari tabel di atas dapat dijelaskan siklus I kualitas paragraf siswa rata-rata berkualitas cukup, cukup maka pada siklus II dan III meningkatkan menjadi baik. Dengan kata lain, paragraf yang ditulis siswa umumnya telah memiliki gagasan utama dan gagasan pengembang yang jelas. Gagasan-gagasan itu dikembangkan secara logis dengan pengorganisasian yang baik. Struktur kalimat dan peralihan antargagasan dalam paragraf sudah memperlihatkan keefektifan, hal tersebut terlihat dari sedikitnya kesalahan dalam penggunaan konjungsi. Kosa-kata yang digunakan juga cukup tepat dan dapat mewakili gagasan yang dikemukakan. Beberapa kesalahan tatabahasa dari mekanik tulisan masih diketemukan, tetapi tidak banyak dan tidak sampai mengaburkan makna gagasan yang dikemukakan.

Selain itu, jumlah pilihan topik tulisan yang dihasilkan, sangat beragam. Hal itu menunjukkan bahwa siswa telah dapat menentukan berbagai bahan, gagasan yang dapat mereka tulis. Keragaman topik tersebut dapat dilihat pada tabel berikut. 
Tabel 3. Topik-Topik Tulisan Siswa selama Pelaksanaan Tindakan Tindakan

\begin{tabular}{|c|l|c|l|}
\hline No & \multicolumn{1}{|c|}{ Topik Tulisan } & No & \multicolumn{1}{|c|}{ Topik Tulisan } \\
\hline 1. & Kenangan Di SD & 17. & Pelajaran dari Buku Bacaanku \\
2. & Keluargaku & 18. & Ringkasan Isi Buku Bacaanku \\
3. & Orang-Orang Disekitarku & 19. & Yang menarik dari Buku Bacaanku \\
4. & Tidak Setuju Hukuman & 20. & Perjuangan Kartini \\
5. & Sahabat Lama & 21. & Pengalaman Hari Kartini \\
6. & Musim lama & 22. & Adikku Berkebaya \\
7. & Musim Jambu Mete & 23. & Memancing \\
8. & Hari Minggu Membosankan & 24. & Pelajaran Hari ini \\
9. & Hobbiku membaca & 25. & Diariku \\
10. & Pengalaman Mengesankan & 26. & Ulang Tahun Kakakku \\
11. & Aku sakit & 27. & Kesendirianku \\
12. & Kepergian Sahabatku & 28. & Kamarku \\
13. & Dihukum Bersama & 29. & Sakitnya Hatiku \\
14. & Hari Minggu Yang Sedih & 30. & Terlambat lagi \\
15. & Tipuan Hadiah & 31. & Disengat Lagi \\
16. & Pasrahku & 32. & Guruku Berubah \\
\hline
\end{tabular}

Keantusiasan, aktivitas, dan motivasi siswa untuk menulis yang semakin meningkat. Hal itu ditandai dengan kemauan siswa membuat buram tulisannya di rumah, walaupun tanpa penugasan dari guru. Siswa cepat menulis di kelas karena umumnya mereka telah memiliki buram yang dibuat di rumah. Siswa juga termotivasi untuk melukis karena merasa tidak mendapat beban tugas yang berat. Tabel berikut menunjukkan perilaku siswa dalam belajar selama siklus penelitian.

Tabel 5. Persentase Keaktifan Siswa Selama Pelaksanaan Tindakan

\begin{tabular}{|c|l|c|c|c|}
\hline \multirow{2}{*}{ No } & \multicolumn{1}{|c|}{ Indikator } & Siklus I & Siklus II & Siklus III \\
\cline { 3 - 5 } & & & & \\
\hline \multirow{4}{*}{1.} & Siswa sangat aktif menulis tiap & $2(8 \%)$ & $4(24 \%)$ & $8(32 \%)$ \\
& Siswa aktif menulis tiap kegiatan & $9(36 \%)$ & $12(48 \%)$ & $14(66 \%)$ \\
& Siswa kurang aktif menulis & $8(32 \%)$ & $4(16 \%)$ & $3(12 \%)$ \\
& Siswa pasif & $6(24 \%)$ & $3(12 \%)$ & - \\
\hline & \multicolumn{1}{|c|}{ Jumlah } & $25(100 \%)$ & $25(100 \%)$ & $25(100 \%)$ \\
\hline
\end{tabular}

Dari tabel di atas terlihat terjadi peningkatan aktivitas siswa selama pelaksanaan tindakan. Pada siklus I masih banyak siswa yang belum atau kurang aktif untuk menilis. Namun, pada siklus II dan III jumlah siswa yang aktif dan sangat aktif menulis terus meningkat. Bahkan, pada akhir siklus III tidak terlihat siswa yang pasif atau tidak menulis jurnalnya.

Peningkatan tersebut dapat tercapai karena bimbingan Guru yang diberikan secara dinamis dan tidak prosedural. Sekalipun menulis jurnal bersifat menulis informasi. Tetapi bimbingan tetap diberikan sehingga dapat menggali ide-ide kreatif siswa dalam menentukan topik dan mengemukakan gagasan. Guru juga berupaya mengaitkan kegiatan menulis jurnal tersebut dengan konteks kehidupan atau materi pembelajaran sehingga gagasan yang ditulis dapat merefleksikan perkembangan hasil belajar dan perkembangan pribadi siswa. Selain itu, respon tertulis yang diberikan yang ternyata mampu meningkatkan motivasi untuk menulis. Motivasi itu tumbuh karena siswa merasa guru menghargai dan peduli dengan apa yang ditulisnya.

Pada awal pembiasaan menulis jurnal, siswa banyak membutuhkan waktu untuk 
menghasilkan sebuah paragraf. Tetapi setelah beberapa kali menulis siswa menjadi semakin terampil. Bahkan dalam perkembangannya siswa mau membuat buram tulisannya di rumah, meskipun guru tidak menugaskan ha1 itu. Dampaknya, pemberian waktu sepuluh sampai lima belas menit yang awalnya terkesan mengurangi waktu pembelajaran pokok dapat dimanfaatkan secara efektif, menjadi berharga, dan lebih bermakna dalam upaya melatih keterampilan menulis siswa.

Dampak positif lain yang ditemukan dari pembiasaan menulis jurnal adalah tumbuhnya kemauan dan keterbukaan siswa untuk mengkomunikasikan atau mengekspresikan secara tertulis berbagai masalah atau peristiwa yang dialami. Selain itu, kebingungan siswa menentukan topik atau kalimat pertama saat mulai menulis dapat teratasi melalui pembiasaan menulis jurnal.

Rangkaian pelaksanaan tindakan menulis jurnal adalah kegiatan penilaian autentik dengan memanfaatkan tulisan-tulisan jurnal siswa. Penilaian autentik ini meliputi kegiatan penilaian diri sendiri, penilaian sejawat antarsiswa, dan penilaian oleh guru. Kegiatan penilaian autentik ini menjembatani kesenjangan antara menulis jurnal sebagai kegiatan menulis informal dengan pembelajaran keterampilan menulis paragraf secara formal di sekolah.

Ada empat indikator peningkatan keterarnpilan menulis paragraf siswa yang tampak sebagai dampak dari tindakan penilaian autentik yang dilakukan oleh siswa. Keempat indikator itu adalah (1) meningkatnya kemampuan mengidentifikasi berbagai kesalahan penggunaan ejaan dan tanda baca yang terdapat dalam sebuah tulisan. (2) meningkatnya kemampuan mengidentifikasi kalimat yang sumbang dalam paragraf (3) meningkatnya kemampuan mengoreksi dan memperbaiki struktur kalimat yang kurang tepat, dan (4) meningkatnya kemampuan untuk mengidentifikasi dan memperbaiki pilihan kata yang kurang tepat.

Penilaian autentik ini juga mendorong siswa untuk mengkonstruksi sendiri pengetahuannya tentang kaidah-kaidah teknik penulisan yang benar karena siswa belajar dari mencermati, mengidentifikasi kesalahan-kesalahan dalam tulisan, dan memperbaiki kesalahan-kesalahan tersebut. Kemampuan mengidentifikasi berbagai kesalahan tersebut mendorong siswa untuk menulis paragraf secara lebih cermat sehingga tidak mengulangi kesalahan serupa saat menulis paragraf dalam jurnal berikutnya. Disisi lain,semangat kerjasama dan percaya diri siswa semakin terbangun melalui kegiatan ini. Siswa belajar untuk bersikap jujur dan berani menilai serta menghargai hasil pekerjaannya sendiri maupun pekerjaan temannya.

Penilaian autentik yang dilakukan guru juga berpengaruh terhadap peningkatan keterarnpilan menulis paragraf siswa karena Guru tidak sekedar memberikan penilaian langsung pada hasil tulisan siswa, tetapi mengumpuikan informasi berdasarkan aktivitas siswa saat menulis dan mencatat kesalahan-Kesalahan yang cenderung dan kerap dilakukan siswa dalam tulisannya. Informasi ini berguna untuk perencanaan dan penyesuaian kebutuhan belajar siswa. Guru juga melakukan penilaian dengan mendokumentasikan perkembangan kualitas tulisan siswa tiap pertemuan secara berkesinambungan karena hasil dokumentasi itu memberikan gambaran tentang peningkatan kemampuan menulis paragraf siswa yang sebenarnya.

\section{PENUTUP \\ Simpulan}

Salah satu permasalahan yang dihadapi dalam pembelajaran bahasa Indonesia di sekolah adalah rendahnya keterampilan menulis paragraf siswa. Hal itu terlihat dari rendahnya kualitas paragraf yang dihasilkan siswa. Siswa juga kurang antusias dan mengalami kesulitan ketika mendapat tugas untuk menulis. Hal tersebut diindikasikan 
karena pembelajaran menulis yang dilakukan belum mendorong dan membentuk kebiasaaan siswa untak menulis. Pembelajaran menulis yang disajikan belum memberi kesempatan banyak pada siswa untuk menulis. Disisi lain penilaian keterampilan menulis juga belum dilakukan secara komprehensif dan berkesinambungan. Untuk mengatasi permasalahan tersebut salah satu alternatif tindakan yang dapat diterapkan adalah penerapan kegiatan menulis jurnal dan memanfaatkan hasil tulisan siswa dalam jurnal untuk penilaian autentik.

Penerapan kegiatan menulis jurnal ini dapat memberikan kesempatan lebih banyak kepada siswa untuk mengekspresikan gagasan secara tertulis. Dengan terbiasa dan lebih sering menulis, kualitas paragraf-paragraf yang dihasilkan dapat semakin baik. Dengan terbiasa menulis kreativitas siswa dalam menulispun meningkat. Siswa semakin mudah dan terbiasa menemukan berbagai bahan atau gagasan yang dapat ditulisnya.

Penerapan autentik oleh siswa maupun guru dengan memanfaatkan hasil tulisan jurnal siswa juga dapat memberi pengaruh yang besar terhadap peningkatan keterampilan menulis paragraf siswa. Dengan menilai hasil tulisannya sendiri maupun hasil tulisan teman; siswa dapat mengkonstruksi dan menemukan sendiri pengetahuannya Siswa belajar dari berbagai kesalahan untuk menulis lebih baik. Di Sisi lain guru juga dapat memanfaatkan hasil autentik tulisan dalam jurnal siswa sebagai sumber informasi untuk melihat perkembangan belajar siswa. Dalam pelaksanaannya. Kegiatan menulis jurnal dan penilaian autentik tersebut dilakukan secara terpadu dan terintegrasi dengan kegiatan pokok pembelajaran bahasa lndonesia.

\section{Saran-Saran} berikut:

Berdasarkan pembahasan hasil penelitian, penulis mengemukakan saran-saran

1. Bagi guru bahasa Indonesia maupun guru matapelajaran lain disarankan kegiatan menulis jurnal ini dapat terus diterapkan dan diintegrasikan dalam pembelajaran karena selain memberikan gambaran tentang perkembangan keterampilan menulis jurnal juga memberikan gambaran tentang berbagai persoalan yang berkaitan dengan hasil belajar dan perkembangan psikologi siswa.

2. Bagi peneliti selanjutnya yang ingin melakukan penelitian tindakan serupa disarankan untuk melakukannya dalam konteks tataran program studi atau mata pelajaran lain karena menulis merupakan proses kognitif dan afektif yang mencakup berbagai bidang.

\section{DAFTAR PUSTAKA}

Depdikbud. 1999. Penelitian Tindakan (Action Research). Bahan Pelatihan Jakarta: Dikdasmen Depdikbud.

Depdiknas. 2003. Kurikulum 2004. Standar Kompetensi Mata Pelajaran Bahasadan Sastra Indonesia SMP dan MTs (Draf Final). Jakarta: Depdiknas.

Elliot, J. 1991. AN. Action Reseach for Educational Change. Buckingham: Open University Press.

Federikson, J. \& Collins, A. 2002. What is Authentic Assesment: Termand Condition of Use. Hougton Mifflin Company (online), (http://www/eduplace.com/ rdg/res/litass/, diakses28Desember2002). 
Laonhardt, M. 2001. 99 Cara Menjadikan Anak Anda Bergairah Menulis. Terjemahan oleh Eva Y.Nukman. 2001. Bandung Kaifa.

Ngalimun. 2013. Bahasa Indonesia di Perguruan Tinggi. Yogyakarta: Aswaja Pressindo

Ngalimun. 2013. Pembelajaran Keterampilan Berbahasa Indonesia. Yogyakarta: Aswaja Pressindo

Ngalimun. 2016. Konsep Dasar Keterampilan Menulis. Yogyakarta: K_Media

Nurhadi \& Senduk, A. G.2003. Pembelajaran Kontekstual dan Penerapannya dalam KBK. Malang: Penerbit Universitas Negeri Malang.

Saukah, Ali. 2001. The Teaching Writing and Grammar. Bahasa dan Seni. Tahun 28, Nomor 2, Agustus 2000, Hal. 191-199.

Suparno, 2001. Pembelajaran Bahasa Indonesia dengan Pendekatan Kontekstual. Makalah disajikan pada Simposium di Wisma Jaya, Bogor. Direktorat SLTP, Dirjen Dikdasmen. November, 2001.

Suyanto, K.E. 2002. Authentic Assesment (Penilaian Otentik) dalam Pembelajaran Bahasa. Materi Pelatihan Calon Pelatih Pembelajaran Kontekstual Mata Pelajaran Bahasa Inggris Guru SLT di Malang. Direktorat SLTP, Depdiknas. 2002.

Tompkins, G.E \& Hoskisson, K. 1991. Language Arts: Contentand Teaching Strategis. New York: Macmillan. 